\title{
A protocol for a systematic review to identify allergenic tree nuts and the molecules responsible for their allergenic properties.
}

DOI:

10.1016/j.fct.2017.06.004

\section{Document Version}

Accepted author manuscript

Link to publication record in Manchester Research Explorer

Citation for published version (APA):

Javed, B., Padfield, P., Sperrin, M., Simpson, A., \& Mills, ENC. (2017). A protocol for a systematic review to identify allergenic tree nuts and the molecules responsible for their allergenic properties. Food and Chemical Toxicology. https://doi.org/10.1016/j.fct.2017.06.004

Published in:

Food and Chemical Toxicology

\section{Citing this paper}

Please note that where the full-text provided on Manchester Research Explorer is the Author Accepted Manuscript or Proof version this may differ from the final Published version. If citing, it is advised that you check and use the publisher's definitive version.

\section{General rights}

Copyright and moral rights for the publications made accessible in the Research Explorer are retained by the authors and/or other copyright owners and it is a condition of accessing publications that users recognise and abide by the legal requirements associated with these rights.

\section{Takedown policy}

If you believe that this document breaches copyright please refer to the University of Manchester's Takedown Procedures [http://man.ac.uk/04Y6Bo] or contact uml.scholarlycommunications@manchester.ac.uk providing relevant details, so we can investigate your claim.

\section{OPEN ACCESS}




\section{Accepted Manuscript}

A protocol for a systematic review to identify allergenic tree nuts and the molecules responsible for their allergenic properties

Bushra Javed, Philip Padfield, Matthew Sperrin, Angela Simpson, E.N. Clare Mills

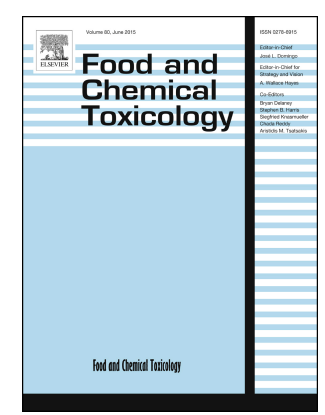

PII: S0278-6915(17)30312-5

DOI: 10.1016/j.fct.2017.06.004

Reference: $\quad$ FCT 9111

To appear in: Food and Chemical Toxicology

Received Date: 6 March 2017

Revised Date: 12 May 2017

Accepted Date: 3 June 2017

Please cite this article as:

This is a PDF file of an unedited manuscript that has been accepted for publication. As a service to our customers we are providing this early version of the manuscript. The manuscript will undergo copyediting, typesetting, and review of the resulting proof before it is published in its final form. Please note that during the production process errors may be discovered which could affect the content, and all legal disclaimers that apply to the journal pertain. 


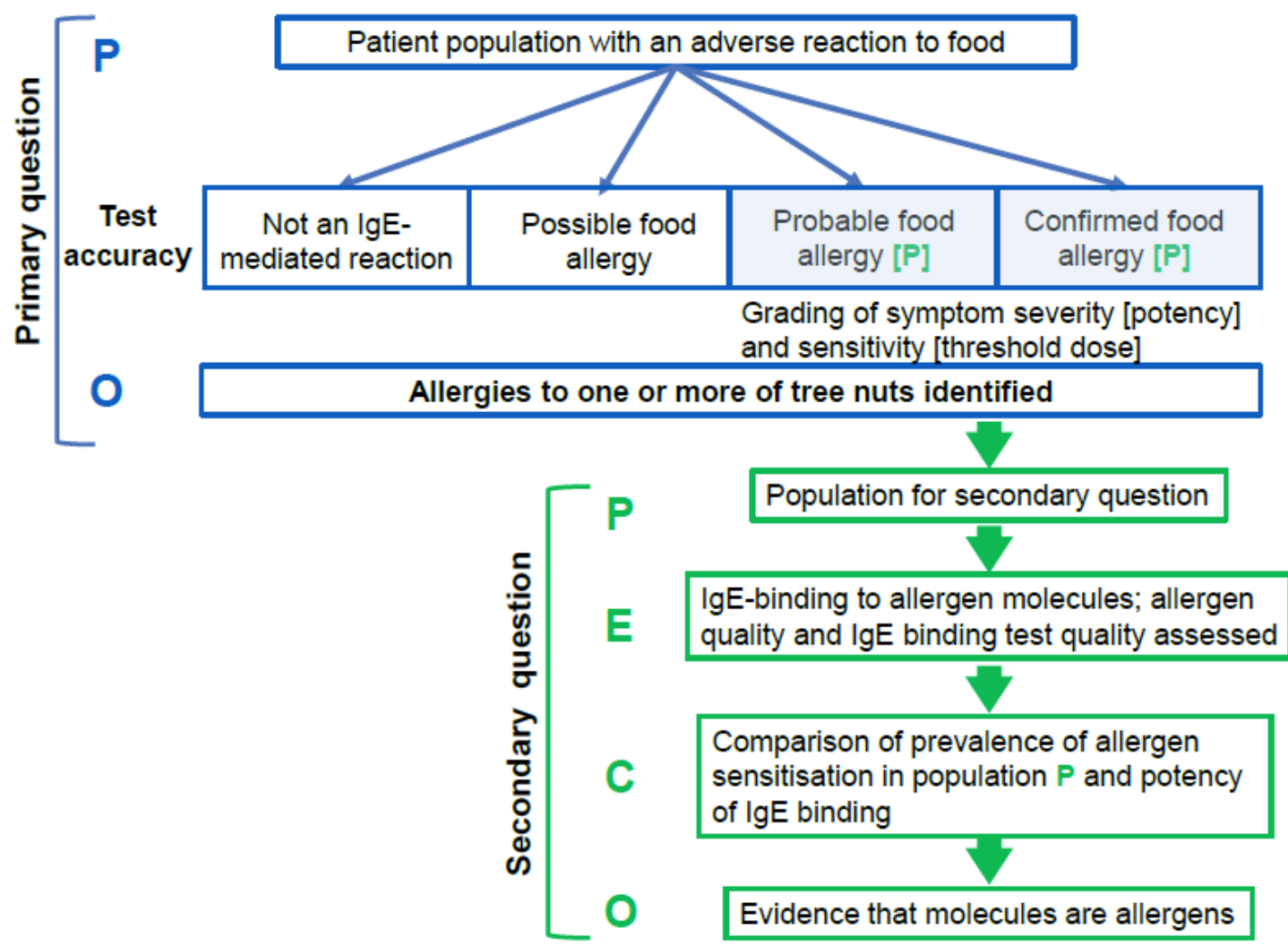

What is the evidence that the clinical manifestation of an IgE-mediated allergic reaction is caused by ingestion of a particular tree nut species?

Which tree nut molecules are
recognised by serum-IgE from
tree nut allergic individuals
and are responsible for
causing an IgE-mediated
adverse reaction to those
foods?




\section{A protocol for a systematic review to identify allergenic tree nuts and the molecules} responsible for their allergenic properties.

Bushra Javed $^{\mathrm{a}, \mathrm{b}}$, Philip Padfield ${ }^{\mathrm{a}}$, Matthew Sperrin ${ }^{\mathrm{c}}$, Angela Simpson ${ }^{\mathrm{b}, \mathrm{d}}$ and E.N. Clare Mills $^{\mathrm{a}, \mathrm{b}}$.

${ }^{\mathrm{a}}$ Manchester Institute of Biotechnology, ${ }^{\mathrm{b}}$ Division of Infection, Immunity and Respiratory, School of Biological Sciences, ${ }^{c}$ Division of Informatics, Imaging and Data Sciences, School of Health Sciences, Manchester Academic Health Science Centre, Faculty of Biology, Medicine and Health, The University of Manchester and ${ }^{\mathrm{d}}$ University Hospital of South Manchester, Manchester, M17DN UK

Correspondence: Professor Clare Mills, Manchester Institute of Biotechnology, The University of Manchester, 131 Princess Street, Manchester, M1 7DN, UK

Email:clare.mills@manchester.ac.uk 


\section{Abstract}

Food regulations require that tree nuts and derived ingredients are included on food labels in order to help individuals with IgE-mediated allergies to avoid them. However, there is no consensus regarding which tree nut species should be included in this definition and specified on food labels. Allergen detection methods used for monitoring foods target allergen molecules, but it not clear which are the most relevant molecules to choose. A modified population-exposure-comparators-outcome (PECO) approach has been developed to systematically review the evidence regarding (1) which allergenic tree nuts should be included in food allergen labelling lists and (2) which are the clinically relevant allergens which should be used as analytical targets. A search strategy and criteria against which the evidence will be evaluated have been developed. The resulting evidence will be used to rank tree nuts with regards their ability to cause IgE-mediated allergies, and allergen molecules regarding their capacity to elicit an allergic reaction. The results of the systematic review will enable risk assessors and managers to identify tree nut species that should be included in food allergen labelling lists and ensure analytical methods for determination of allergens in foods are targeting appropriate molecules.

\section{Highlights}

- A protocol is proposed to systematically review the evidence that tree nuts and tree nut proteins cause IgE-mediated allergies.

- An evidence-based ranking approach is described to identify tree nuts and allergen molecules causing allergic reactions.

- Outcomes will help identify which tree nut species should be included on allergen lists and support selection of analytical target molecules. 


\section{Keywords}

Tree nut; food allergy; allergen molecule; systematic review; PECO 


\section{Background}

IgE-mediated food allergy affects approximately $1.5 \%$ of adults and 5-6\% of children in Europe although most infants and young children "outgrow" their food allergy by school age (Nwaru et al., 2014) with tree nuts being estimated to cause around 0-1.9\% of food allergies (McWilliam et al., 2015). The prevalence of food allergy varies around the world, and whilst sensitisation to a wide variety of foods is high in countries like India, the prevalence of probable food allergy is low (Mahesh et al., 2016) and whilst differences in methodology may in part be responsible for these variations it is becoming clear that genetic and environmental factors also contribute (Rona et al., 2007, Nwaru et al., 2014, McWilliam et al., 2015). Whilst more than 170 different foods have been reported to cause IgE-mediated allergic reactions, (Hefle et al., 1996) the majority of allergies are caused by a relatively small number of foods including egg, milk, fish, shellfish, peanut and tree nuts (Nwaru et al., 2014, McWilliam et al., 2015, Venter et al., 2016). Since there is currently no accepted therapy for food allergy, individuals diagnosed with the condition must practise food avoidance, often life-long. Those individuals thought to be at risk of having a severe reaction are also given rescue medication such as anti-histamines and self-injectable adrenaline, should they accidentally consume some of their problem food.

In order to help allergic consumers avoid their problem food, a list of priority allergenic foods have to be labeled at whatever level they are included in a recipe, based on the foods listed in the Codex Alimentarius Commission labeling recommendations (CodexAlimentariusCommission, 1999). The Codex list includes "tree nuts", although the specific plant species covered by this phrase are not always defined in regulations implemented across the world. In general expert opinion has been used to inform decisions as to which foods should be included in food allergen labeling lists, although systematic 
approaches have been proposed to identify allergenic foods of public health importance that must be actively managed (Bjorksten et al., 2008, Houben et al., 2016b, van Bilsen et al., 2011). In addition to mandatory labeling of allergenic ingredients, precautionary allergen labelling (PAL) may also be used to warn the allergic individual about the unintended presence of allergens through the use of phrases, such as "may contain" (DunnGalvin et al., 2015). Effective analytical methodology is required to help support risk assessment and management of allergenic ingredients using approaches such as those developed by the Voluntary Incidental Trace Allergen Labelling (VITAL) expert group (Taylor et al., 2014). Analysis of allergens is used for both in validating cleaning protocols in factories as well as monitoring ingredients and finished foods for unintended allergens. However, there are many limitations with current allergen analysis (Walker et al., 2016) and it is not always clear which allergen molecules represent the hazard for allergic consumers and should be used as analytical targets for new methods, such as protein mass spectrometry.

We propose to undertake a systematic review of the literature to assess the strength of evidence supporting the inclusion of particular tree nut species in priority lists of allergenic foods, and to help identify clinically relevant allergenic molecules in those foods to be used as analytical targets in allergen analysis. (McWilliam et al., 2015, Venter et al., 2016). The application of systematic reviewing to food hazards, such as allergens, is relatively novel, and it is recognised that there is a need to adapt protocols used in medicine to the needs of evidence-based toxicology (Stephens et al., 2016). We have developed a protocol for the systematic review built on an approach previously described for identifying allergenic foods of public health importance (Bjorksten et al., 2008, Houben et al., 2016a, van Bilsen et al., 2011). It is based on guidance provided by the European Food Safety Authority (EFSA, 2010) which draws on approaches developed in the health care field (Higgins and Green, 2011, CRD, 2009) and applies PRISMA guidelines (Moher et al., 2009) . 


\section{Study design}

The primary question being addressed is "What is the evidence that the clinical manifestation of an IgE-mediated allergic reaction is caused by ingestion of a particular tree nut species?"

The secondary question being addressed is "Which tree nut molecules are recognised by serum-IgE from tree nut allergic individuals and are responsible for causing an IgEmediated adverse reaction to those foods?"

Figure 1: Framework for the systematic review approach using a Population -Outcome (PO) and a modified Population-Exposure-Comparator-Outcome (PECO) approach. The PO approach (shown in blue) will be used to answer the primary question "What is the evidence that the clinical manifestation of an IgE-mediated allergic reaction is caused by ingestion of a particular tree nut species?". A modified PECO approach (shown in green) will be used to address the secondary question "Which tree nut molecules are recognised by serum-IgE from tree nut allergic individuals and are responsible for causing an IgEmediated adverse reaction to those foods?" 


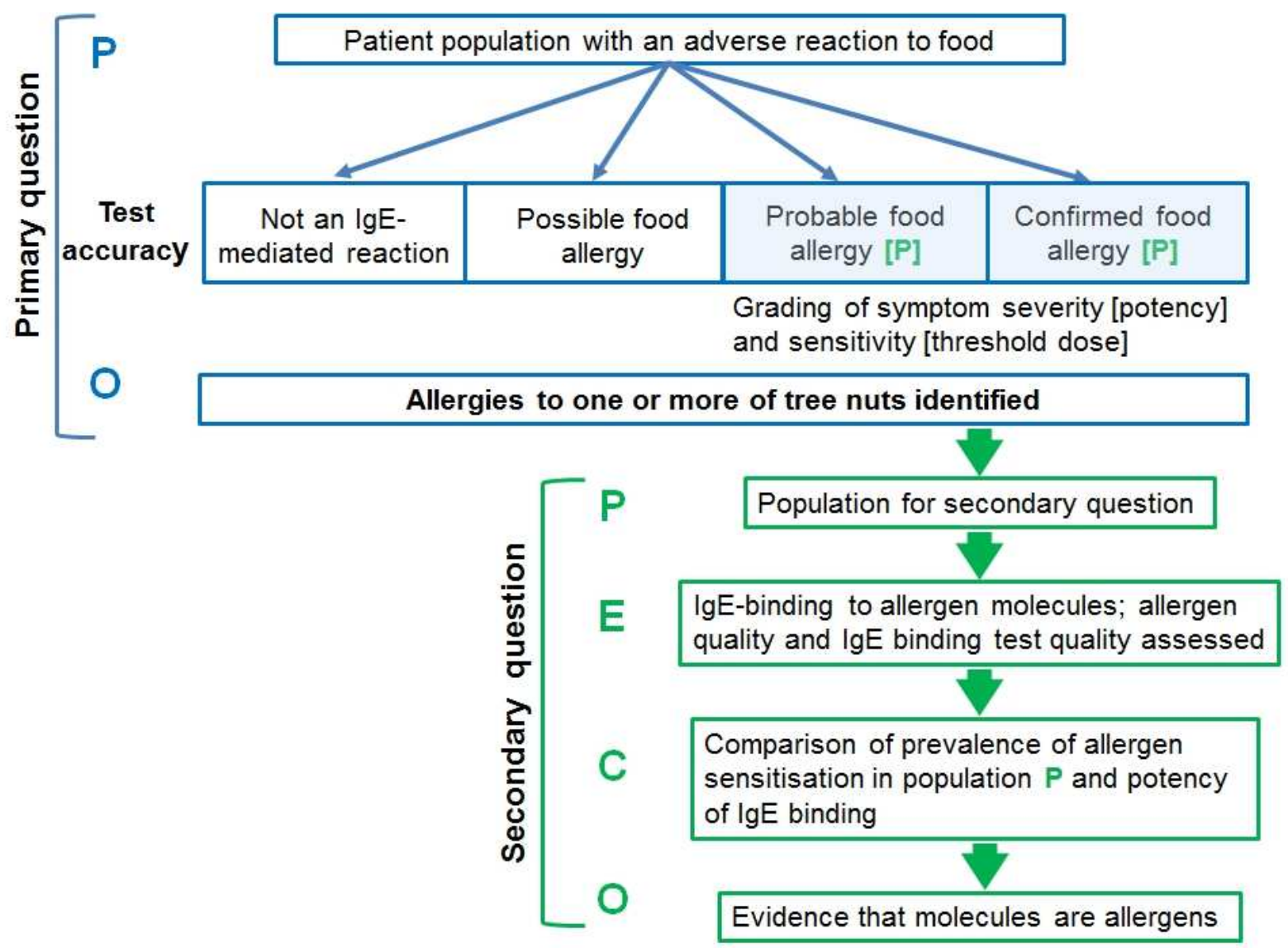


The primary question will be addressed using a PO approach (EFSA, 2010) the population $(\mathrm{P})$ being the patient population evaluated for an IgE-mediated allergy to food and the outcome $(\mathrm{O}$; or condition of interest) being whether they suffer from IgEmediated allergy to tree nuts (Figure 1). The population can include patients drawn from either prospective cohort studies, longitudinal cohorts, or cross-sectional studies and case series. The outcome is then graded with regards the quality of diagnosis (test accuracy), based on the principals laid out in the EAACI Food Allergy Guidelines (Muraro et al., 2014, Soares-Weiser et al., 2014) and criteria proposed by Bjorksten and co-workers (Bjorksten et al., 2008). This will allow the quality of studies and the evidence that documented adverse reactions are caused by an IgE-mediated mechanism to be assessed and provide some indication of the severity of reactions.

The secondary question will be addressed using a modified population, exposure, comparator and outcome (PECO) (EFSA, 2010) approach (Table 1; Figure 1). In the modified approach the population is the one identified in addressing the primary question that has been classified as having either probable or confirmed food allergy. The exposure (E) element of PECO is taken as the exposure to tree nut allergens as indicated by the detection of tree-nut specific serum IgE and/or positive skin prick testing with tree nuts, tree-nut extracts or purified tree nut allergens. The test accuracy will be assessed in terms of the quality of the IgE binding studies performed together with the quality of the allergen extracts and purified allergens used. The comparison $(\mathrm{C})$ is then made with regards the prevalence of sensitisation to the different allergen molecules in the population $(\mathrm{P})$. The allergens will also be compared with regards their potency as indicated by their ability to bind IgE or trigger mediator release in an effector cell assay, such as the stripped-basophil histamine release assay. The outcome [O] relates to the evidence indicating that a particular allergen molecule is responsible for eliciting IgE- 
Table 1: Modified population, exposure, comparator and outcome (PECO) approach developed to address the secondary question.

\begin{tabular}{|l|l|}
\hline Population (P) & \begin{tabular}{l} 
What is the evidence the population had an IgE- \\
mediated allergy to a tree nut? [Identified by addressing \\
the primary question using a PO approach] \\
How many subjects in the population with tree nut allergy have \\
serum-IgE that binds a particular tree nut protein extract or \\
purified allergen molecules? \\
\hline Comparator (C)
\end{tabular} \\
$\begin{array}{l}\text { How do different allergens compare with regards } \\
\text { (1) The extent of sensitisation in the relevant tree-nut } \\
\text { allergic population; } \\
\text { (2) Their potency in terms of binding IgE and/or } \\
\text { activating effector cells involved in driving } \\
\text { allergic reactions. } \\
\text { Outcomes (O) }\end{array}$ & $\begin{array}{l}\text { What is the quality of evidence that a particular } \\
\text { molecule can cause an IgE-mediated reaction? }\end{array}$ \\
\hline
\end{tabular}

mediated allergic reactions in the population. If data are of sufficient quality, some indication of their potency may also be assessed through a meta-analysis of outcomes, such as skin prick test wheal diameter or levels of allergen specific $\operatorname{IgE}$.

\section{Search strategy}

Initially a list of tree nuts included in allergen labelling legislation in Europe, USA and other jurisdictions was compiled (Supplementary file 1). Currently 31 countries and one jurisdiction in the world have implemented food allergen labelling regulations, and three countries have proposed a food allergen legislation draft for consideration. Several have 
listed specific tree nut species and these were used as the basis to defining the search terms (Table 2). These search terms will be applied with validated study designed filters for retrieving any other relevant systematic reviews (Wilczynski and Haynes, 2007) and sound diagnostic studies (Wilczynski and Haynes, 2005) and used to search MEDLINE (OVID), ISI Web of Science, and Scopus (Falagas et al., 2008) from inception to 30August-2017. Additional references will be located through searching the allergenic food database InformAll, a searchable technical database for food allergy (plant and animal allergenic foods), hosted by the University of Manchester and based on peer reviewed articles which have been reviewed by a panel of expert referees (InformAll). This will be complimented by searching the references cited in the papers identified in the search, technical reports and other literature that has not been peer reviewed but is publicly available. The database will be searched without language restrictions. If the abstract of a non-English article is identified as being relevant, where possible, it will be translated into English. The research process will be fully documented to will allow the search to be assessed and reproduced.

Table 2: Search terms identified for different tree nuts

\begin{tabular}{|l|l|l|}
\hline Common names & Latin Name & Search terms \\
\hline Almond & Prunus dulcis & Almond* AND Allerg* \\
\hline Beechnut & Fagus species & Fagus OR Beechnut* AND Allerg* \\
\hline Brazil nut & Bertholletia excelsa & Brazil AND (Nut OR Nuts) AND \\
\hline Butter nut & Allerg* \\
\hline Cashew nut & Juglans cinerea & Butter AND (Nut OR Nuts) AND \\
& & Allerg* \\
\hline
\end{tabular}




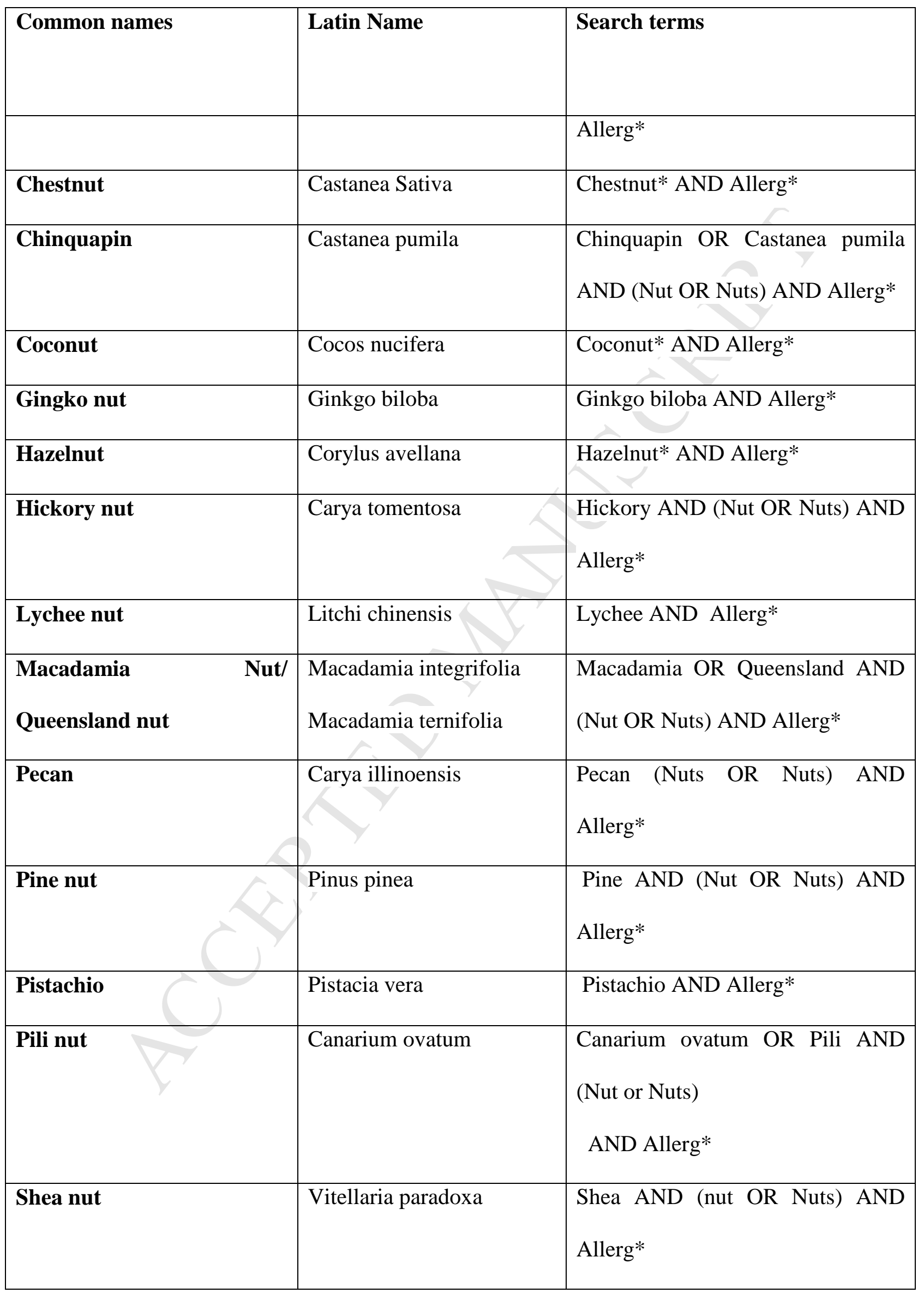




\begin{tabular}{|l|l|l|}
\hline Common names & Latin Name & Search terms \\
\hline Walnut & Juglans regia & Walnut* AND Allerg* \\
\hline
\end{tabular}

\section{Study selection}

Articles identified in the searches will be evaluated against inclusion and exclusion criteria defined in Table 3. All references will be uploaded into EndNote and duplicate copies of the same article be removed using a combination of automatic (using software such as Distiller) and manual screening. Study titles and abstracts will be independently reviewed by two team members (BJ, ENCM) using the selection criteria described above and categorised as included, excluded, and unsure. The full text of research studies in the unsure category will be retrieved and re-categorised as included or excluded. Discrepancies will be resolved by discussion with the whole team (BJ, ENCM, AS, PP and MS).

Table 3: Inclusion and exclusion criteria used for selection of primary studies.

\begin{tabular}{|c|c|}
\hline Inclusion & Exclusion \\
\hline $\begin{array}{l}\text { (i) Peer-reviewed articles. } \\
\text { (ii) Articles directly related to the defined } \\
\text { research questions. } \\
\text { (iii) Articles not closely related to the topic of } \\
\text { the research question (IgE binding } \\
\text { molecules) but provide information about } \\
\text { patients from whom serum samples were } \\
\text { obtained to characterise the allergen (e.g. }\end{array}$ & $\begin{array}{l}\text { (i) Full text is unavailable. } \\
\text { (ii) Studies that do not describe the IgE- } \\
\text { binding molecules or are unrelated to } \\
\text { the question being addressed. } \\
\text { (iii) The abstract and summary of the } \\
\text { following will not be included in the } \\
\text { study: book chapters, non-peer } \\
\text { reviewed case reports or case studies, }\end{array}$ \\
\hline
\end{tabular}




\begin{tabular}{|l|l|l|}
\hline Inclusion & Exclusion & \\
\hline clinical manifestation) and those & editorial materials which are \\
providing information about the & expressing the opinion of the editor or \\
physicochemical characteristics and & publisher, meetings, conferences, \\
biological activity of allergens. & seminars, & workshops, \\
(iv) Only include those case studies or case & symposiums, patents and proceeding \\
reports which are peer reviewed and & papers. & \\
related to IgE- mediated food allergy & (iv) Review articles. \\
where an IgE-binding molecule is & (v) Animal model studies. & \\
described. & &
\end{tabular}

\section{Quality assessment strategy}

Tabulation will be used to make a summary for exploring the differences and similarities between the studies and studies will be ranked as described in Table 4. Quality assessment of each study will be carried out independently using the Critical Appraisal Skill Program check-lists (CASP). 
Table 4: Criteria for assessing the quality of evidence that a population is sensitised to a particular allergenic tree nut or allergen molecule.

\begin{tabular}{|l|l|}
\hline Quality level & Criteria \\
\hline $1 \mathrm{a}$ & $\begin{array}{l}\text { Patterns of sensitisation determined in unselected study } \\
\text { populations or nested case control studies across } \\
\text { multiple study centres }\end{array}$ \\
\hline $1 \mathrm{~b}$ & $\begin{array}{l}\text { Patterns of sensitisation determined in unselected study } \\
\text { populations or nested case control studies in a single } \\
\text { study centres }\end{array}$ \\
\hline $2 \mathrm{a}$ & $\begin{array}{l}\text { Surveys of out-patient clinic patients across multiple } \\
\text { study centres }\end{array}$ \\
\hline $3 \mathrm{~b}$ & Surveys of out-patient clinic patients in a single study \\
& Centre \\
\hline
\end{tabular}

To assess the risk of bias in the studies, the Cochrane guideline will be used to examine each secondary study (Higgins and Green, 2011). During the review of secondary studies, a numerical scaling approach was developed to allow weighting of the contribution made by a particular line of evidence to the overall estimate (i.e. a single scale or score). Clarification was provided for each level of evidence (lowest to highest). The grading will be performed independently by two people (BJ, ENCM) and a justification for each of the scores given to each paper will be noted and compared at the end through open discussion with the whole study team (BJ, ENCM, AS, PP and MS). The grading criteria developed uses four key questions and indicative scores given to each category as follows. 
The population under study: The highest quality grade will be given to those patients who have confirmed food allergy with an oral food challenge or a history of anaphylaxis following consumption tree nuts, and associated sensitisation to the relevant food, taking into account the quality measure of the study as defined by Bjorksten et al (Bjorksten et al., 2008) (Tables 4 and 5). A lower quality grade will be given to those patients who had evidence of sensitisation to the relevant food and a convincing history of a reaction within $2 \mathrm{~h}$ of consuming their problem food [probably food allergy]. The lowest grading will be given to patients for whom data are only available regarding either their self-reported allergy to tree nuts or sensitisation to tree nuts determined either by measurement of specific $\operatorname{IgE}$ or skin prick testing [possible food allergy].

The exposure under study: The concept of exposure relates to identifying how many subjects in the population with tree nut allergy have been exposed to a particular molecule from a given tree nut species (or a closely homologous molecule) and developed serum-IgE to that molecule. Two types of test accuracy will be applied, one that relates to the quality of the allergen preparations used (Table 6) and a second which relates to the methodology used to assess IgE binding (Table 7). 
Table 5: Criteria for grading the evidence that a tree nut species causes IgE-mediated food allergy (the primary question)

\begin{tabular}{|c|c|}
\hline $\begin{array}{l}\text { Level of } \\
\text { evidence }\end{array}$ & Criteria \\
\hline $1 \mathrm{a}$ & $\begin{array}{l}\text { A history of anaphylaxis or IgE mediated allergy is confirmed with } \\
\text { DBPCFC and evidence of sensitisation to the food (supported by skin } \\
\text { prick test, and/or food specific serum IgE) [confirmed food allergy]. }\end{array}$ \\
\hline $1 \mathrm{~b}$ & $\begin{array}{l}\text { A history of anaphylaxis / allergy is confirmed with an open or single } \\
\text { blinded food challenge, and evidence of sensitisation to the food } \\
\text { (supported by skin prick test, and/or food specific serum IgE) [confirmed } \\
\text { food allergy]. }\end{array}$ \\
\hline 2 & $\begin{array}{l}\text { History of immediate reactions to the problem food with } 2 \mathrm{~h} \text { of } \\
\text { consumption, associated with sensitisation to the food (supported by skin } \\
\text { prick test, and/or food specific serum IgE [probable food allergy]. }\end{array}$ \\
\hline 3 & $\begin{array}{l}\text { - Convincing history with symptoms consistent with an IgE- } \\
\text { mediated allergic reaction or; } \\
\text { - Sensitisation alone, proven using specific IgE testing or a skin } \\
\text { prick test [possible food allergy]. }\end{array}$ \\
\hline & No evidence of causing IgE-mediated allergies. \\
\hline
\end{tabular}


Table 6: Quality ranking of the different types of allergen molecule preparation and their quality characteristics

\begin{tabular}{|l|l|}
\hline Quality level & Allergen preparation and characterisation \\
\hline 1 & Well-characterised purified native allergen (sequence \\
confirmation and mass data) \\
\hline 2 & Purified native with N-terminal sequence \\
\hline 3 & Recombinant allergen with confirmed sequence, \\
folding and aggregation information \\
\hline 4 & Native allergen with no sequence information \\
\hline 5 & Recombinant allergen without folding and \\
& aggregation confirmation \\
\hline 6 & Partial purified allergen \\
\hline
\end{tabular}

To evaluate the quality of the allergen preparation, it is important to know what type of allergen preparation has been used in the study (is it a crude allergen extract, native purified protein or recombinant protein?). It is also relevant to assess an allergen's folded state and any aggregation or postranslational modifications which could affect the $\operatorname{IgE}$ binding ability of the allergen molecule (Hoffmann-Sommergruber et al., 2008).

The quality of the methodology used to determine a molecules capacity to bind IgE also needs to be considered (Table 7). In vivo tests include oral or labial challenges and skin testing (i.e. skin prick test and prick-to-prick test) whereas in vitro tests include effector cell activation using mast cells, basophils (patient's own or stripped basophils) and 
animal cell lines humanised with the human high affinity IgE receptor. Such methods test whether an allergen has the folded state and multiple IgE binding sites which allow crosslinking of cellular-bound IgE, an important quality characteristic of an authentic allergen (Hoffmann-Sommergruber et al., 2008). Other methods which simply demonstrate IgE binding capacity include immunoassay including immunodiagnostics such as ImmunoCAP and ISAC, and immunoblotting methods. Each method has its own performance parameters (including sensitivity and specificity). Since in vivo methodologies were ranked more highly than the in vitro tests and since the effector cells include a measure of the ability of an allergen to trigger histamine release and is biologically more closely related to the events occurring in an allergic reaction, these in vitro tests were ranked more highly than those simply measuring food specific IgE.

Table 7: Quality ranking of the different types of test used to define whether a particular allergen molecule can induce an IgE-mediated reaction

\begin{tabular}{|c|c|}
\hline Quality level & Criteria \\
\hline 1 & In vivo challenge in an allergic patient. \\
\hline 2 & Skin prick test. \\
\hline 3 & $\begin{array}{l}\text { Effector cell activation (e.g. basophil histamine release) } \\
\text { using either cells or serum samples from food allergic } \\
\text { patients. }\end{array}$ \\
\hline 4 & $\begin{array}{l}\text { IgE-immunoassay using serum samples from food } \\
\text { allergic patients. }\end{array}$ \\
\hline 5 & $\begin{array}{l}\text { IgE-dot blotting with a purified protein or } \\
\text { immunoblotting following separation of allergen } \\
\text { molecules using, for example, SDS-PAGE, and serum }\end{array}$ \\
\hline
\end{tabular}




\begin{tabular}{|l|l|}
\hline & samples from food allergic patients. \\
\hline 6 & $\begin{array}{l}\text { Dot blotting using allergen extracts and serum samples } \\
\text { from food allergic patients. }\end{array}$ \\
\hline
\end{tabular}

The comparators under study: The capacity of the different allergen molecules to sensitise a given tree nut allergic population $(\mathrm{P})$ and their potency. Aspects relating to the prevalence of sensitisation will be assessed, taking into account the quality of studies using the grading scheme proposed by Bjorksten et al (Bjorksten et al., 2008). Depending on the quality of data available, potency could be defined in terms of $\mathrm{kUIgE} / \mathrm{L}$ that bind to a specific allergen, the concentration of allergen able to either inhibit IgE binding by $50 \%$ in an inhibition immunoassay or initiate 50\% of mediator release in an effector cell assay or skin prick test mean wheal diameter, which can be used to assign a biological potency to an allergen with regards its capacity to elicit an IgE-mediated allergic reaction used as a comparator.

Analysis and reporting of outcomes: Using an aggregated score based on the grading for $\mathrm{P}$ and $\mathrm{O}$ measures for different tree nuts will allow them to be ranked according to the evidence that they can cause IgE-mediated food allergies and therefore whether they should be included on allergen labelling lists. If the quality of evidence allows, data on measures of potency (e.g. severity of reaction and sensitivity using threshold dose distributions) (Bjorksten et al., 2008) will be integrated with data on prevalence to classify the tree nuts as major, minor or emerging allergenic foods. The outcome of this analysis will show whether a particular tree nut can be identified as causing IgE-mediated allergic reactions. However, before including such foods in food allergen labelling lists other factors need to be taken into account, such as the risk of exposure as indicated by the extent of use and whether a food ingredient can be considered as a "hidden allergen" not readily discerned by the allergic consumer (Bjorksten et al., 2008). If data of sufficient quality and quantity are 
identified, allergen molecules will be ranked with regards the extent to which they sensitise the tree-nut allergic population and their potency, allowing an evidence-based means of selecting the most hazardous allergenic molecules which should be included as targets for allergen analysis.

\title{
Pilot study
}

A pilot study was conducted to validate and evaluate the review protocol to make sure that the process is rigorous, transparent and replicable.

\section{Discussion}

This framework will provide an objective way of assessing the quality of evidence that particular foods can cause IgE-mediated food allergies and subsequently to rank them. Other approaches have been developed using more complex and detailed data such as prevalence, threshold data and impact on quality of life (Houben et al., 2016a). The simplified approach taken in this systematic review may provide a means of ranking foods objectively for which such data are lacking and help support the decision making and prioritisation with regards elaborating the list of tree nut species that should be labelled. The analysis will also allow an evidence-based approach to be taken to identifying allergenic molecules as analytical targets which represent the true hazard for allergic consumers. During the course of the analysis data gaps will be identified.

\begin{abstract}
Abbreviations
CASP: Critical appraisal Skill Program; DBPCFC: double blind placebo controlled food challenges; EAACI: European Academy of Allergy and Clinical Immunology; EFSA: European Food Safety Authority (EFSA); ELISA: enzyme-linked immunosorbent assay; PECO: Population, exposure, compararot and outcome; PAL: Precautionary allergen labelling;
\end{abstract}




\section{Declarations]}

Ethics approval and consent to participate: Not applicable.

Consent for publication: Not applicable

Availability of data and material: Not applicable.

Conflicts of interest: BJ, PP, AS and MC declare that they have no competing interests.

ENCM is an ad hoc expert to the UK Food Standards Agency Advisory Committee on Novel Foods and Processes and a member of the European Food Safety Authority self-task group on Allergenicity risk assessment for the GMO panel.

Funding: None

Authors' contributions: BJ: Bushra Javed; ENCM: E.N. Clare Mills; AS: Angela Simpson;

PP: Phil Padfield; MS: Matthew Sperrin; BJ and CM have developed the study protocol and drafted the publication; PP, MS and AS have critically evaluated the protocol and contributed to revising the publication.

\section{References}

BJORKSTEN, B., CREVEL, R., HISCHENHUBER, C., LOVIK, M., SAMUELS, F., STROBEL, S., TAYLOR, S. L., WAL, J. M. \& WARD, R. 2008. Criteria for identifying allergenic foods of public health importance. Regul Toxicol Pharmacol, 51, 42-52.

CASP Critical appraisal Skill Program (CASP) http://media.wix.com/ugd/dded87_a02ff2e3445f4952992d5a96ca562576.pdf.

CODEXALIMENTARIUSCOMMISSION 1999. Codex General Standard for the Labelling of Prepackaged Foods. . CODEX STAN 1-1985 (Rev. 1-1991).

CRD 2009. Systematic Reviews, York, UK, York Publishing Services Ltd.

DUNNGALVIN, A., CHAN, C. H., CREVEL, R., GRIMSHAW, K., POMS, R., SCHNADT, S., TAYLOR, S. L., TURNER, P., ALLEN, K. J., AUSTIN, M., BAKA, A., BAUMERT, J. L., BAUMGARTNER, S., BEYER, K., BUCCHINI, L., FERNANDEZ-RIVAS, M., GRINTER, K., HOUBEN, G. F., HOURIHANE, J., KENNA, F., KRUIZINGA, A. G., LACK, G., MADSEN, C. B., CLARE MILLS, E. N., PAPADOPOULOS, N. G., ALLDRICK, A., REGENT, L., SHERLOCK, R., WAL, J. M. \& ROBERTS, G. 2015. Precautionary allergen labelling: perspectives from key stakeholder groups. Allergy, 70, 1039-51. 
EFSA 2010. Application of systematic review methodology to food and feed safety assessments to support decision making; EFSA Guidance for those carrying out systematic reviews. EFSA Journal 8, 1637.

FALAGAS, M. E., PITSOUNI, E. I., MALIETZIS, G. A. \& PAPPAS, G. 2008. Comparison of PubMed, Scopus, web of science, and Google scholar: strengths and weaknesses. The FASEB journal, 22, 338-342.

HEFLE, S. L., NORDLEE, J. A. \& TAYLOR, S. L. 1996. Allergenic foods. Crit Rev Food Sci Nutr, 36 Suppl, S69-89.

HIGGINS, J. P. T. \& GREEN, S. 2011. Cochrane Handbook for Systematic Reviews of Interventions Version 5.1.0 [updated March 2011]. . The Cochrane Collaboration.

HOFFMANN-SOMMERGRUBER, K., MILLS, E. N. \& VIETHS, S. 2008. Coordinated and standardized production, purification and characterization of natural and recombinant food allergens to establish a food allergen library. Mol Nutr Food Res, 52 Suppl 2, S159-65.

HOUBEN, G., BURNEY, P., CHAN, C.-H., CREVEL, R., DUBOIS, A., FALUDI, R., ENTINK, R. K., KNULST, A., TAYLOR, S. \& RONSMANS, S. $2016 a$.

Prioritisation of allergenic foods with respect to public health relevance. Food and Chemical Toxicology.

HOUBEN, G., BURNEY, P., CHAN, C. H., CREVEL, R., DUBOIS, A., FALUDI, R., KLEIN ENTINK, R., KNULST, A., TAYLOR, S. \& RONSMANS, S. 2016 b. Prioritisation of allergenic foods with respect to public health relevance: Report from an ILSI Europe Food Allergy Task Force Expert Group. Food Chem Toxicol, 89, 8-18.

INFORMALL InformAll: Communicating about Food Allergies; University of Manchester http://www.inflammationrepair.manchester.ac.uk/informall/allergenic-foods/.

MAHESH, P. A., WONG, G. W., OGORODOVA, L., POTTS, J., LEUNG, T. F., FEDOROVA, O., HOLLA, A. D., FERNANDEZ-RIVAS, M., CLARE MILLS, E. N., KUMMELING, I., VERSTEEG, S. A., VAN REE, R., YAZDANBAKHSH, M. \& BURNEY, P. 2016. Prevalence of food sensitization and probable food allergy among adults in India: the EuroPrevall INCO study. Allergy, 71, 1010-9.

MCWILliAM, V., KOPLIN, J., LODGE, C., TANG, M., DHARMAGE, S. \& ALLEN, K. 2015. The Prevalence of Tree Nut Allergy: A Systematic Review. Curr Allergy Asthma Rep, 15, 54.

MOHER, D., LIBERATI, A., TETZLAFF, J., ALTMAN, D. G. \& GROUP, P. 2009. Preferred reporting items for systematic reviews and meta-analyses: the PRISMA statement. PLoS med, 6, e1000097.

MURARO, A., WERFEL, T., HOFFMANN-SOMMERGRUBER, K., ROBERTS, G., BEYER, K., BINDSLEV-JENSEN, C., CARDONA, V., DUBOIS, A., DUTOIT, G. \& EIGENMANN, P. 2014. EAACI food allergy and anaphylaxis guidelines: diagnosis and management of food allergy. Allergy, 69, 1008-1025.

NWARU, B. I., HICKSTEIN, L., PANESAR, S. S., ROBERTS, G., MURARO, A. \& SHEIKH, A. 2014. Prevalence of common food allergies in Europe: a systematic review and meta-analysis. Allergy, 69, 992-1007. 
RONA, R. J., KEIL, T., SUMMERS, C., GISLASON, D., ZUIDMEER, L., SODERGREN, E., SIGURDARDOTTIR, S. T., LINDNER, T., GOLDHAHN, K., DAHLSTROM, J., MCBRIDE, D. \& MADSEN, C. 2007. The prevalence of food allergy: a meta-analysis. J Allergy Clin Immunol, 120, 638-46.

SOARES-WEISER, K., TAKWOINGI, Y., PANESAR, S., MURARO, A., WERFEL, T., HOFFMANN-SOMMERGRUBER, K., ROBERTS, G., HALKEN, S., POULSEN, L. \& REE, R. 2014. The diagnosis of food allergy: a systematic review and meta-analysis. Allergy, 69, 76-86.

STEPHENS, M. L., BETTS, K., BECK, N. B., COGLIANO, V., DICKERSIN, K., FITZPATRICK, S., FREEMAN, J., GRAY, G., HARTUNG, T., MCPARTLAND, J., ROONEY, A. A., SCHERER, R. W., VERLOO, D. \& HOFFMANN, S. 2016. The Emergence of Systematic Review in Toxicology. Toxicol Sci, 152, 10-6.

TAYLOR, S. L., BAUMERT, J. L., KRUIZINGA, A. G., REMINGTON, B. C., CREVEL, R. W., BROOKE-TAYLOR, S., ALLEN, K. J. \& HOUBEN, G. 2014. Establishment of Reference Doses for residues of allergenic foods: report of the VITAL Expert Panel. Food Chem Toxicol, 63, 9-17.

VAN BILSEN, J. H., RONSMANS, S., CREVEL, R. W., RONA, R. J., PRZYREMBEL, H., PENNINKS, A. H., CONTOR, L. \& HOUBEN, G. F. 2011. Evaluation of scientific criteria for identifying allergenic foods of public health importance. Regul Toxicol Pharmacol, 60, 281-9.

VENTER, C., PATIL, V., GRUNDY, J., GLASBEY, G., TWISELTON, R., ARSHAD, S. H. \& DEAN, T. 2016. Prevalence and cumulative incidence of food hypersensitivity in the first 10 years of life. Pediatr Allergy Immunol, 27, 452-8.

WALKER, M. J., BURNS, D. T., ELLIOTT, C. T., GOWLAND, M. H. \& MILLS, E. N. 2016. Is food allergen analysis flawed? Health and supply chain risks and a proposed framework to address urgent analytical needs. Analyst, 141, 24-35.

WILCZYNSKI, N. L. \& HAYNES, R. B. 2005. EMBASE search strategies for identifying methodologically sound diagnostic studies for use by clinicians and researchers. BMC Med, 3, 7.

WILCZYNSKI, N. L. \& HAYNES, R. B. 2007. EMBASE search strategies achieved high sensitivity and specificity for retrieving methodologically sound systematic reviews. J Clin Epidemiol, 60, 29-33. 